\title{
Mesoarchean mafic magmatism from two distinct mantle sources: Evidence from Sm-Nd isotopic studies on metabasalts of the Gadag greenstone belt, Dharwar craton, India
}

\author{
D. KAMALAKANNAN ${ }^{12^{*}}$ AND S. BALAKRISHNAN ${ }^{1}$
}

${ }^{1}$ Department of Earth Sciences, Pondicherry University, Puducherry-605014.

(balakrishnan.srinivasan@gmail.com)

${ }^{2}$ G\&IG Division, NCEGR, GSI, Kolkata-700091.

(*correspondence: geokamal842004@gmail.com)

The auriferous Gadag greenstone belt (GGB) occurs to north of the Chitradurga greenstone belt in the western Dharwar craton. Chadwick et al. [1] suggested that the belt consists of five distinct tectonic domains, trending NW-SE, bound by shear zones. Metabasaltic rocks with pillow structures are reported from Doni, Attikatti and Vadvi domains. They are studied for geochemistry and Sm-Nd isotope systematic to determine their petrogenesis and ages.

Metabasalts occur as chlorite actinolite schist (CAS) in the Doni domain and they define a $\mathrm{Sm}-\mathrm{Nd}$ whole-rock isochron age of $3025 \pm 100 \mathrm{Ma}\left(\mathrm{MSWD}=4.2,{ }^{143} \mathrm{Nd} /{ }^{144} \mathrm{Nd}_{\mathrm{i}}=\right.$ 0.50870). Whereas, metabasalts (MB) from Attikatti and Vadvi domains are massive, fine grained and show porphyritic texture. They yielded a $\mathrm{Sm}-\mathrm{Nd}$ isochron age of $2863 \pm 100 \mathrm{Ma}\left(\mathrm{MSWD}=2.9,{ }^{143} \mathrm{Nd} /{ }^{144} \mathrm{Nd}_{\mathrm{i}}=0.50899\right)$. In the absence of correlation between $1 / \mathrm{Nd}$ vs. $\varepsilon_{\mathrm{Nd}}$ for CAS and MB both ages are interpreted to represent time of their formation. The $\varepsilon_{\mathrm{Nd}}$ values of CAS samples $(\mathrm{t}=3025)$ range from -0.12 to -0.47 , except one sample G6B $(+0.72)$ and the $\varepsilon_{\mathrm{Nd}}(\mathrm{t}=2863)$ of MB samples are varying from +0.87 to +1.84 . Magmas representing CAS of the Doni domain was derived from mantle source that was metasomatized for long time or contaminated with less radiogenic $\mathrm{Nd}$ derived from $>3.5 \mathrm{Ga}$ old continental crust, prior to melting. Magmas representing MB of the Attikatti and Vadvi domains were derived from long term LREE depleted mantle sources. Thus mafic metavolcanic rocks of GGB were formed at different periods and tapped distinct mantle sources and were later juxtaposed tectonically.

[1] Chadwick et al. (2003) J. Geol. Soc. India, 61,645-663. 